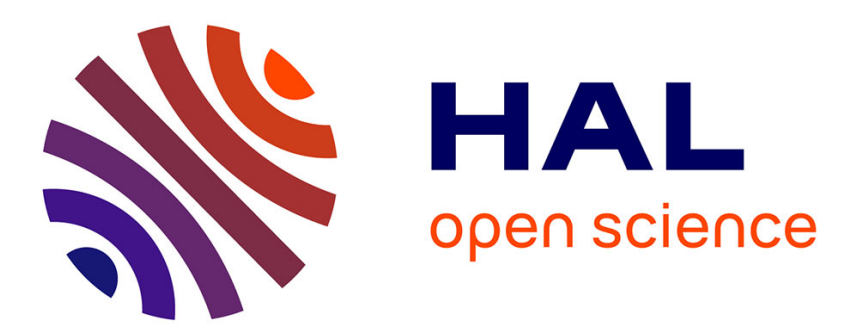

\title{
Impact of cooking on apricot texture as a function of cultivar and maturity
}

Jamal Ayour, Barbara Gouble, Patrice Reling, Albert Ribas, Jean Marc Audergon, Jean Francois Maingonnat, Mohamed Benichou, Catherine M.G.C. Renard

\section{To cite this version:}

Jamal Ayour, Barbara Gouble, Patrice Reling, Albert Ribas, Jean Marc Audergon, et al.. Impact of cooking on apricot texture as a function of cultivar and maturity. LWT - Food Science and Technology, 2017, 85 (Part B), pp.385-389. 10.1016/j.lwt.2016.10.040 . hal-01608395

\section{HAL Id: hal-01608395 \\ https://hal.science/hal-01608395}

Submitted on 26 May 2020

HAL is a multi-disciplinary open access archive for the deposit and dissemination of scientific research documents, whether they are published or not. The documents may come from teaching and research institutions in France or abroad, or from public or private research centers.
L'archive ouverte pluridisciplinaire HAL, est destinée au dépôt et à la diffusion de documents scientifiques de niveau recherche, publiés ou non, émanant des établissements d'enseignement et de recherche français ou étrangers, des laboratoires publics ou privés. 


\title{
Impact of cooking on apricot texture as a function of cultivar and maturity
}

\author{
Jamal Ayour a, b, *, Barbara Gouble ${ }^{\text {b }}$, Patrice Reling ${ }^{\text {b }}$, Albert Ribas-Agustí b , \\ Jean-Marc Audergon ${ }^{\mathrm{c}}$, Jean-François Maingonnat ${ }^{\mathrm{b}}$, Mohamed Benichou ${ }^{\mathrm{a}}$, \\ Catherine M.G.C. Renard ${ }^{\mathrm{b}}$ \\ a Faculté des sciences Semlalia, Université Cadi Ayyad, Laboratoire Sciences des Aliments, M-40090 Marrakech, Maroc \\ b INRA, Université d'Avignon et des Pays du Vaucluse, UMR408 Sécurité et Qualité des Produits d'Origine Végétale, F-84000 Avignon, France \\ c INRA, UR1052 Génétique et Amélioration des Fruits et Légumes, F-84143 Montfavet, France
}

\section{A R T I C L E I N F O}

\section{Article history:}

Received 30 June 2016

Received in revised form

29 September 2016

Accepted 15 October 2016

Available online $\mathrm{xxx}$

\section{Keywords:}

Prunus armeniaca $\mathrm{L}$.

Penetrometry

Flesh firmness

Processing

\begin{abstract}
A B S T R A C T
The rapid loss of fruit firmness is a qualitative decisive factor for characterizing apricot (Prunus armeniaca L.) use (fresh or processed) and commercialization pathways (short or storage). To better understand the texture variability in apricot, we studied the impact of a heat treatment as a function of fruit harvest stage on a large range of cultivars. Eighteen apricot cultivars were characterized at two maturity stages before and after cooking ( $85{ }^{\circ} \mathrm{C}$ in light syrup). A compression test allowed sorting the fruits to obtain homogeneous batches. Kramer shear tests provided global firmness of cooked fruits and puncture tests were performed on the median equatorial area of apricot flesh for fresh and cooked fruits. Among the registered variables, the apricot texture expressed by the "Work to limit" integrates the global evolution and allows a good discrimination of the ripening effect. The texture data was used to classify the varieties according to their firmness and suitability for industrial processing. Thus Vertige, Candide and Gaterie, followed by Orangered and Bergarouge, have been found as the most suitable cultivars for industrial processes.
\end{abstract}

(C) 2016 Elsevier Ltd. All rights reserved.

\section{Introduction}

Apricot (Prunus armeniaca L.) is a fleshy fruit of economic and nutritional interest. With a world production of 4.04 million tons in 2012 (FAOSTAT, 2013), it is the third most widely grown stone fruit, after peach and plum. The fruit is consumed fresh or processed in dried, canned apricot, jam, marmalade, pulp, juice, etc. However, the commercialization and the marketing of apricots are difficult because of their rapid softening and the associated susceptibility to physical damage and disease (DeMartino, Massantini, Botondi, \& Mencarelli, 2002; Kovacs, Meresz, Kristof, \& Németh-Szerdahel, 2008; Ella Missang, Maingonnat, Renard, \& Audergon, 2011).

Firmness and texture are important quality attributes for apricot fruit; they influence consumer acceptability, postharvest manipulation, storage shelf-life, microbial susceptibility and suitability for

\footnotetext{
* Corresponding author. Faculté des sciences Semlalia, Université Cadi Ayyad, Laboratoire Sciences des Aliments, M-40090 Marrakech, Maroc.

E-mail address: jamal.ayour@alumni.univ-avignon.fr (J. Ayour).
}

processing into different products. Commonly, apricot fruits are harvested firm (thus early) to limit damage during handling and shipping. However at this stage, the other quality attributes such as appearance, taste, aroma and nutritional value are not sufficiently developed (Botondi, Crisà, Massantini, \& Mencarelli, 2000; Bruhn et al., 1991). In addition, apricots appear to be particularly sensitive to softening during cooking which is a limiting factor in processing technology, marketing and use of apricots and their products. During preparation of halved apricots, safety requires that the fruit reach at least $85^{\circ} \mathrm{C}$ at heart. Only little information is available on texture of canned apricot fruit (Chitarra, Labavitch, \& Kader, 1989; Ella Missang et al., 2011; Mallidis \& Katsaboxakis, 2002). Some varieties have poor resistance to heat, which causes disintegration of the fruit (Ella Missang et al., 2011). Apricot is also characterized by high heterogeneity in its tissue structure, with five layers: an epidermis, a hypodermal layer, a middle layer of thin walled parenchyma cells, a layer of radially elongated cells and a layer of small cells adjacent to the pit (Archibald \& Melton, 1987). These five layers have different responses during thermal treatment (Ella Missang et al., 2011) with the median equatorial area 
appearing the most representative for texture characterization in the fruit.

Our aim was to identify apricot cultivars suitable for processing to canned halves, by characterizing texture alteration after processing. The impact of the harvest stage and the effect of heat treatment $\left(85^{\circ} \mathrm{C}\right)$ have been characterized on the median equatorial area of the fruits of 18 representative apricot cultivars.

\section{Materials and methods}

\subsection{Plant materials}

Apricot fruits were harvested in 2015 in INRA orchards at Amarine (Gard, France) and Gotheron (Drôme, France). The 18 apricot cultivars selected were: A4034, A5350, Bergarouge ${ }^{\circledR}$ Avirine, Bergeron, Candide, Congat, Elgat, Frisson, Gaterie, Goldrich, Helena du Roussillon ${ }^{\circledR}$ Aviera, Hargrand, Moniqui, Orangered ${ }^{\circledR}$ Bhart, Polonais, Ravilong (A3759), Tardif de Bordaneil and Vertige. About 160 fruits from each cultivar were harvested slightly after the conventional date and brought to the laboratory within $2-3 \mathrm{~h}$ for sorting in maturity classes by compression ( $\S 2.3 .1$ ). Maturity stages were defined as: $\mathrm{M} 1=130 \mathrm{kPa} \pm 5 \mathrm{kPa}$ (commercial) and $\mathrm{M} 2=100 \mathrm{kPa} \pm 5 \mathrm{kPa}$ (half-ripe). One batch of 32 fruits for each stage was sorted for each cultivar, each batch being subdivided into 12 fruits for test on fresh fruits and 20 fruits for test after cooking.

\subsection{Preparation of cooked apricots}

The heat treatment was performed in light syrup, based on sucrose commercial sugar cane syrup diluted to $16^{\circ} \mathrm{B}$. Fruit halves (one half per fruit) were dropped into the syrup at $70^{\circ} \mathrm{C}$ and cooked until $85{ }^{\circ} \mathrm{C}$ at heart (the temperature were controlled using a thermocouple and the time needed was about $20 \mathrm{~min}$ ). After cooking, fruits were cooled to room temperature on iced water.

\subsection{Texture analysis}

\subsubsection{Sorting of whole fruit in firmness classes}

Whole fruit firmness was measured with a compression test that gives a combination of skin resistance and flesh firmness (Grotte, Duprat, Loonis, \& Pietri, 2001). The measurement consists in determining the pressure $(\mathrm{Pa})$ required to compress whole apricots by $3 \%$ of their equatorial height with a texturometer (Penelaup, Serisud, Nimes, France) equipped with flat disc $(5 \mathrm{~cm}$ diameter) (probe speed $=100 \mathrm{~mm} / \mathrm{min}$ ).

\subsubsection{Puncture tests}

Puncture tests were realized on 12 fresh and 10 cooked halves. For each, a tissue slice of about $1.5 \mathrm{~cm}$ thick was cut longitudinally. The median equatorial area (Fig. S1) was retained according to Ella Missang et al. (2011) and Ella Missang, Maingonnat, Renard, and Audergon (2012).

The puncture was made using a multi-purpose texturometer (Tplus, Ametek, Lloyd, Fareham, UK) equipped with a $50 \mathrm{~N}$ load cell (flat cylindrical probe, $2 \mathrm{~mm}$ diameter, $100 \mathrm{~mm} / \mathrm{min}$ penetration rate, $9 \mathrm{~mm}$ depth). Different parameters were registered from the force/displacement curves: Maximum Load $\left(\mathrm{F}_{\max }, \mathrm{N}\right)$, Deflection at Maximum Load (DefF $\left.\mathrm{max}_{\max }, \mathrm{mm}\right)$, Work to Maximum Load $\left(\mathrm{W}_{\max }, \mathrm{J}\right)$, Load at Limit $\left(\mathrm{F}_{\text {lim }}, \mathrm{N}\right)$, Work to Limit $\left(\mathrm{W}_{\text {lim }}, \mathrm{J}\right)$ and Load average for the plateau $\left(F_{p}, N\right)$; this last variable was calculated only for fresh fruit (Fig. S2a).

\subsubsection{Kramer shear test}

Kramer shear test was performed using the same multi-purpose texturometer but equipped with a $1000 \mathrm{~N}$ load cell. Ten cooked apricots halves were cut longitudinally and divided into three batches corresponding to three replicates. About 120-130 g of cooked fruit slices was placed perpendicular in the Kramer (K) cell and sheared at $20 \mathrm{~cm} / \mathrm{min}$ speed. Registered parameters (Fig. S2b) expressed for $100 \mathrm{~g}$ of cooked fruit are: Maximum Load $\left(\mathrm{F}_{\max } \mathrm{rK}, \mathrm{N}\right)$, Work to Maximum Load $\left(\mathrm{WF}_{\max } \mathrm{rK}, \mathrm{J}\right)$ and Work to Limit $\left(\mathrm{WF}_{\text {lim }} \mathrm{rK}\right.$, $\mathrm{J})$.

\subsection{Statistical analysis}

Standard deviations of the means were calculated for each series of duplicates using the sum of individual variances pondered by the individual degrees of freedom (Box, Hunter, \& Hunter, 1978). Statistical analysis was performed using IBM SPSS Statistics 19 software. ANOVA and cluster analysis were carried out for the 18 apricot cultivars on all measured parameters. For each variety and maturity stage, data set corresponds to replications on 12 fresh fruits, 10 cooked fruits and 3 fruit batches.

\section{Results and discussion}

\subsection{Impact of processing on texture profile}

The puncture test allowed acquiring two types of profiles (Fig. 1), one for fresh fruits and the other for cooked fruits. These typical force/displacement profiles are frequently found in other fruit and vegetables such as apple (Costa, 2016), carrot and jicama (Nguyen et al., 2010).

Fresh fruit firmness is characterized in a first stage by a slope related to the elasticity of apricot flesh, needing a higher force for initial penetration. After cooking, the same pattern is observed with a lower slope value and a larger displacement. At the end of that phase the maximum load is registered for both fresh and cooked tissues, for most of the cultivars. In fresh apricots, $\mathrm{F}_{\max }$ values range between $1 \mathrm{~N}$ and $4.5 \mathrm{~N}$ after $1.5 \mathrm{~mm}-2 \mathrm{~mm}$ of penetration. In cooked fruits, $F_{\max }$ values are lower and range between 0.2 and $0.8 \mathrm{~N}$ after $4-5 \mathrm{~mm}$ of penetration (Fig. 1 ).

After $F_{\max }$, the second part of the curve is characterized by a periodic pattern, which could be linked to the presence of conductive vessels in the flesh. For cooked apricots, the shape of the curve seemed close to that of the fresh fruits but more attenuated.

The correlation analysis (Table 1 ) between registered parameters on all fresh cultivars at M1 stage highlights the relationships

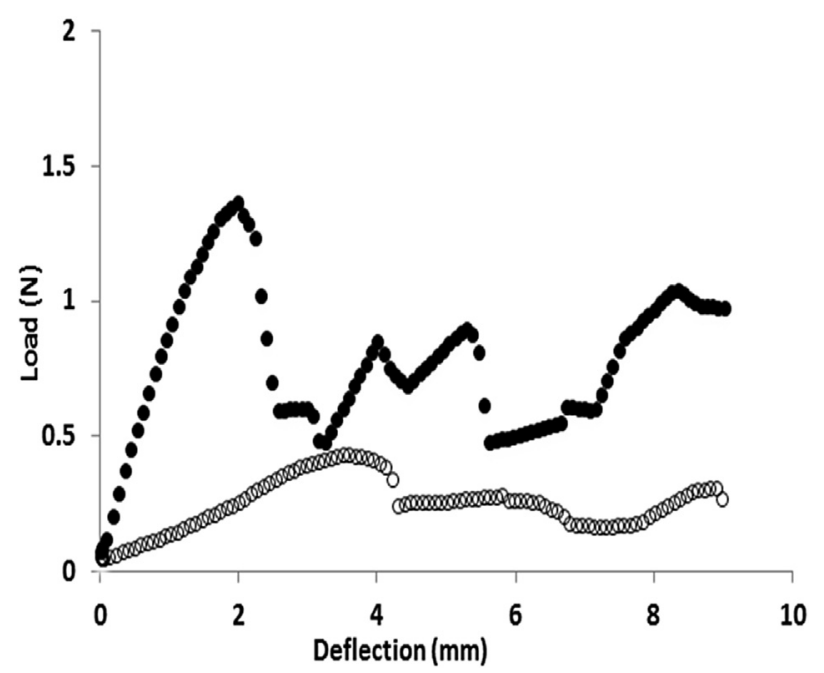

Fig. 1. Typical puncture curves on the median equatorial area for fresh $(\bullet)$ and cooked (O) apricot: example of Orangered ${ }^{\circledR}$ Barth (cov) at half ripe maturity (M2). 
Table 1

Correlation matrix between the texture parameters of penetration curve (Load/ Deflection) measured on median equatorial area for all cultivars at commercial (M1) stage.

\begin{tabular}{lllllll}
\hline Variables & $\mathrm{F}_{\max }$ & $\operatorname{DefF}_{\max }$ & $\mathrm{W}_{\max }$ & $\mathrm{F}_{\text {lim }}$ & $\mathrm{W}_{\text {lim }}$ & $\mathrm{F}_{\mathrm{p}}$ \\
\hline $\mathrm{F}_{\max }$ & 1.000 & -0.116 & 0.647 & $\mathbf{0 . 9 7 6}^{*}$ & $\mathbf{0 . 9 9 1}^{*}$ & $\mathbf{0 . 8 9 5}^{*}$ \\
$\operatorname{DefF}_{\max }$ & & 1.000 & 0.102 & 0.008 & -0.084 & -0.060 \\
$\mathrm{~W}_{\max }$ & & & 1.000 & 0.723 & 0.679 & 0.686 \\
$\mathrm{~F}_{\lim }$ & & & & 1.000 & $\mathbf{0 . 9 8 8}^{*}$ & $\mathbf{0 . 8 9 3}^{*}$ \\
$\mathrm{~W}_{\lim }$ & & & & & 1.000 & $\mathbf{0 . 9 2 6}^{*}$ \\
$\mathrm{~F}_{\mathrm{p}}$ & & & & & & 1.000 \\
\hline
\end{tabular}

Note: $\mathrm{F}_{\max }$ : Maximum Load; DefF $\mathrm{F}_{\max }$ : Deflection at Maximum Load; $\mathrm{W}_{\max }$ : Work to Maximum Load; $F_{\text {lim: }}$ : Load at Limit; $W_{\text {lim }}$ : Work to Limit; $F_{p}$ : average Load for the plateau; *: High level of correlation significance $(\mathrm{P}<0.05)$.

between the components of the texture. Strong positive correlations were found between all variables except DefF $F_{\max }$. The work to limit $\left(\mathrm{W}_{\text {lim }}\right)$ was chosen as being relevant for all force-related parameters and being the most integrative measure.

\subsection{Interaction of cultivar and maturity with processing}

The classification of the cultivars according to $\mathrm{W}_{\text {lim }}$ (driven by M1 fresh values) indicated huge differences between cultivars whatever the maturity stages for fresh and cooked fruits (Fig. 2). Although all apricots had been sorted for similar resistances to compression, the $\mathrm{W}_{\mathrm{lim}}$ values for $\mathrm{M} 1$ fresh fruit ranged from about 28 to $4 \mathrm{~mJ}$ respectively for Vertige and A3759, with most of the cultivars being around $10 \mathrm{~mJ}$. As expected, the $\mathrm{W}_{\mathrm{lim}}$ values decreased with maturity, with M2 fresh fruits ranging from about 21 to $4 \mathrm{~mJ}$ respectively for Vertige and A3759 plus A5350, with most of the cultivars ranging between 11 and $4 \mathrm{~mJ}$. Rather good consistency is noticed between the observations performed at M1 and M2 stages, only minor changes were observed in the classification, like for A4034 and Goldrich.

After cooking, $W_{\text {lim }}$ values for $M 1$ maturity stage highly decreased, ranging from 13 to $2 \mathrm{~mJ}$ respectively for Vertige and A3759 with most of the cultivars being around $5 \mathrm{~mJ}$, and the classification is partly modified (Fig. 2). Even lower values were observed for M2 stage.

The effects of the three factors (cultivar, maturity, cooking) on $\mathrm{W}_{\text {lim }}$ was highly significant (Table S1). The impact of cooking was the largest, followed by maturity stage and cultivar. The interaction between variety and maturity or cooking was significant but rather low. This indicates that the pronounced effect of cooking (and maturation) was different for the different varieties, i.e. texture loss is influenced by the genetic background. Multi-range comparison tests (Table 2) have classified the cultivars in 6-7 groups according to maturity and process. It expressed the huge influence of the cultivars. The average impact of cooking was around 53\% whatever the maturity stage (from 34 to $72 \%$ for M1 and from 14 to $72 \%$ for M2). On fresh fruits the average impact of the maturity stage (M1 vs $\mathrm{M} 2$ ) onto the final $\mathrm{W}_{\text {lim }}$ score was around $25 \%$, evolving between 7 (Congat) and 42\% (A4034) according to the cultivar. On cooked fruits, the average impact was similar (27\%), reaching $56 \%$ for Moniqui.

Vertige, Gaterie, Candide and Orangered were the firmest apricots before and after cooking at the two ripening stages, so they could be expected as the more suitable cultivars for industrial process. Except Vertige, these firmest cultivars were also among the most affected by the maturity stage, with around $40 \%$ loss between M1 and M2 cooked fruits, such as Bergarouge (5 1 \% loss). Concurrently A3759, A5350, Elgat and Goldrich appeared not appropriate for processing to apricot halves, being the most sensitive to texture loss during cooking.

As puncture tests on other areas have underlined other differences between cultivars (data not shown), it appeared interesting to have a global firmness indication on cooked fruits with the Kramer shear test, more related to an industrial evaluation. The Kramer shear test allowed another classification of the cultivars based on the $\mathrm{W}_{\text {lim }}$ values at M1 stage but most cultivars are not separated, regardless of the maturity stages (Table 3). Hargrand distinguishes itself with its low resistance to heat treatment $\left(\mathrm{W}_{\mathrm{lim}}\right.$ values between $3.1 \mathrm{~J}$ and 2.6 J for M1 and M2 stages), while Candide and especially Orangered apricots were the most resistant, so the most suitable for heat treatment, at the two ripening stages (13 J

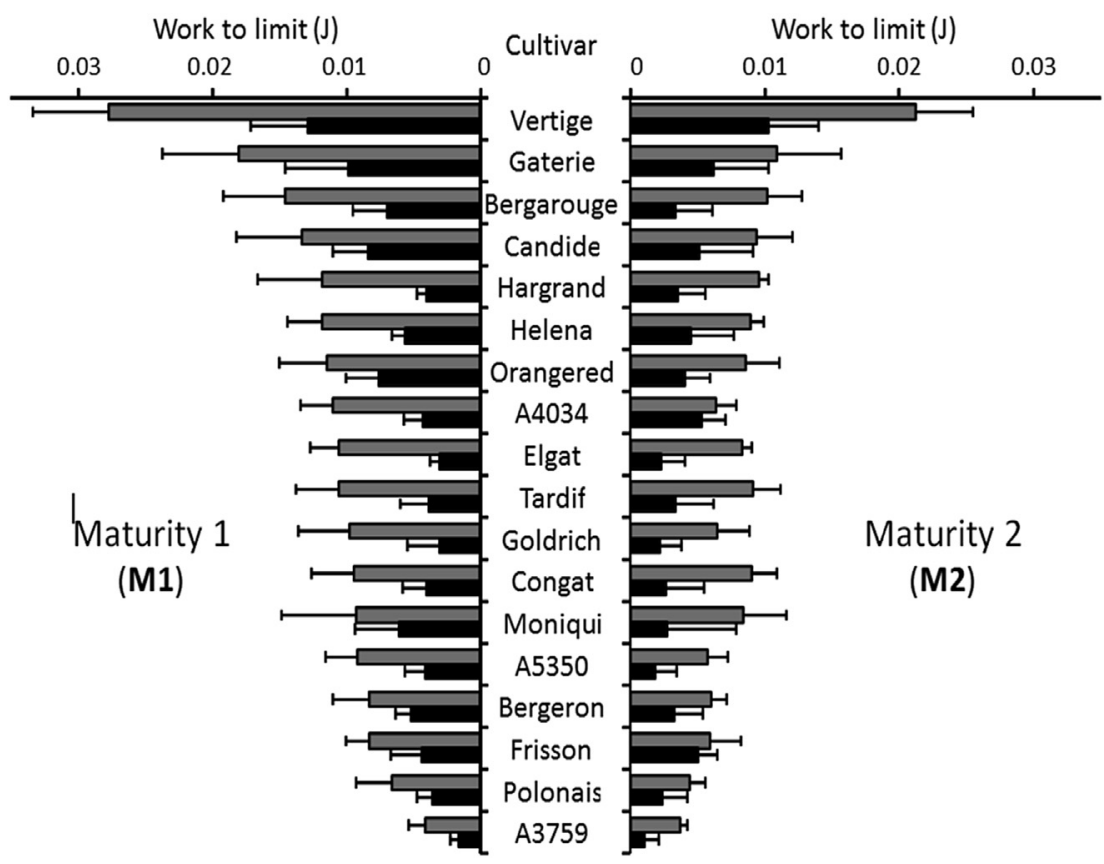

Fig. 2. Apricot cultivar classification according to the work to limit $\left(\mathrm{W}_{\mathrm{lim}}\right)$ for median equatorial area puncture test. Grey bars: fresh fruits; black bars: cooked fruits. 
Table 2

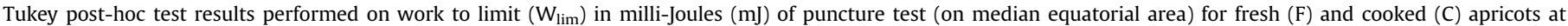

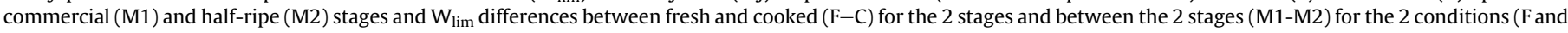
C).

\begin{tabular}{|c|c|c|c|c|c|c|c|c|}
\hline \multirow[t]{2}{*}{ Cultivars } & \multicolumn{3}{|c|}{ Commercial stage (M1) } & \multicolumn{3}{|c|}{ Half-ripe stage (M2) } & \multicolumn{2}{|c|}{ (M1-M2) } \\
\hline & Fresh & Cooked & $(\mathrm{F}-\mathrm{C}) \%$ & Fresh & Cooked & $(\mathrm{F}-\mathrm{C}) \%$ & Fresh \% & Cooked \% \\
\hline Vertige & $27.6 \mathrm{a}$ & $12.9 \mathrm{a}$ & 53 & $21.3 \mathrm{a}$ & $10.2 \mathrm{a}$ & 52 & 23 & 21 \\
\hline Gaterie & $18.1 \mathrm{~b}$ & $9.8 \mathrm{ab}$ & 46 & $10.9 \mathrm{~b}$ & $6.2 \mathrm{~b}$ & 43 & 40 & 37 \\
\hline Bergarouge & 14.6 bc & 6.9 bcde & 53 & $10.2 \mathrm{bc}$ & 3.4 cdefg & 67 & 30 & 51 \\
\hline Candide & $13.4 \mathrm{bcd}$ & $8.3 \mathrm{bc}$ & 38 & $9.4 \mathrm{bcd}$ & $5.1 \mathrm{bcd}$ & 46 & 30 & 39 \\
\hline Hargrand & $11.8 \mathrm{cde}$ & 3.9 defg & 67 & $9.5 \mathrm{bcd}$ & 3.5 cdefg & 63 & 19 & 10 \\
\hline Helena & 11.8 cde & $5.6 \mathrm{cdef}$ & 52 & $8.9 \mathrm{bcd}$ & 4.5 bcde & 49 & 25 & 20 \\
\hline Orangered & 12.3 cde & 7.6 bcd & 38 & $8.5 \mathrm{bcd}$ & 4.1 cdef & 52 & 31 & 46 \\
\hline A4034 & 11.0 cde & 4.2 defg & 62 & $6.4 \mathrm{cdef}$ & $5.3 \mathrm{bc}$ & 17 & 42 & -26 \\
\hline Elgat & 10.6 cde & $3.0 \mathrm{fg}$ & 72 & 8.3 bcde & $2.3 \mathrm{efg}$ & 72 & 22 & 23 \\
\hline Tardif de Bordaneil & 10.5 cde & 3.8 defg & 64 & $9.1 \mathrm{bcd}$ & 3.4 cdefg & 63 & 13 & 10 \\
\hline Goldrich & 9.8 cde & $3.1 \mathrm{fg}$ & 68 & $6.5 \mathrm{cdef}$ & $2.2 \mathrm{efg}$ & 66 & 34 & 30 \\
\hline Congat & 9.6 cdef & 3.9 defg & 59 & 8.9 bcd & 2.6 defg & 71 & 7 & 33 \\
\hline Moniqui & 9.2 cdef & $6.1 \mathrm{cdef}$ & 34 & $8.4 \mathrm{bcd}$ & 2.7 defg & 68 & 9 & 56 \\
\hline A5350 & 9.2 cdef & 4.0 defg & 56 & 5.8 def & $1.9 \mathrm{fg}$ & 67 & 37 & 52 \\
\hline Bergeron & 8.3 def & 5.2 cdefg & 37 & 6.1 def & 3.3 cdefg & 16 & 26 & 36 \\
\hline Frisson & 8.2 def & 4.4 defg & 46 & 5.9 def & $5.1 \mathrm{bcd}$ & 14 & 28 & -16 \\
\hline Polonais & 6.6 ef & 3.6 efg & 45 & 4.4 ef & $2.4 \mathrm{efg}$ & 45 & 33 & 33 \\
\hline A3759 & $4.1 \mathrm{f}$ & $1.6 \mathrm{~g}$ & 61 & $3.7 \mathrm{f}$ & $1.1 \mathrm{fg}$ & 70 & 10 & 31 \\
\hline Pooled SD & 3.7 & 2.3 & & 2.7 & 1.6 & & & \\
\hline
\end{tabular}

Each value is the mean of 12 replicates for fresh apricot and 10 replicates for cooked apricot.

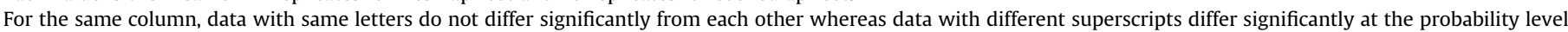
$\mathrm{P}<0.05$; Pooled SD: Pooled standard deviation.

\section{Table 3}

Tukey post-hoc test results performed on work to limit $\left(\mathrm{W}_{\mathrm{lim}}\right)$ in Joules of Kramer shear test for both maturity stages of cooked apricots and differences between the 2 stages (M1-M2). Cultivar order is from the highest value (Candide) to the lower (Hargrand) at M1 stage.

\begin{tabular}{llll}
\hline Cultivar & Commercial stage (M1) & Half-ripe stage (M2) & M1-M2 (\%) \\
\hline Candide & $13.3 \mathrm{ab}$ & $9.1 \mathrm{ab}$ & 31 \\
Orangered & $12.1 \mathrm{ab}$ & $10.2 \mathrm{a}$ & 16 \\
Helena & $11.7 \mathrm{abc}$ & $8.9 \mathrm{ab}$ & 24 \\
Gaterie & $11.1 \mathrm{abc}$ & $6.3 \mathrm{cde}$ & 43 \\
Polonais & $10.7 \mathrm{abcd}$ & $8.4 \mathrm{abc}$ & 22 \\
Bergarouge & $10.5 \mathrm{bcd}$ & $8.3 \mathrm{abc}$ & 21 \\
Tardif de Bordaneil & $10.1 \mathrm{bcd}$ & $7.6 \mathrm{bcd}$ & 25 \\
Vertige & $9.7 \mathrm{bcdef}$ & $8.9 \mathrm{ab}$ & 9 \\
Moniqui & $9.3 \mathrm{cdef}$ & $7.2 \mathrm{bcd}$ & 23 \\
Bergeron & $9.3 \mathrm{cdefg}$ & $6.3 \mathrm{cde}$ & 32 \\
A4034 & $8.1 \mathrm{defgh}$ & $7.1 \mathrm{bcd}$ & 13 \\
A3759 & $8.0 \mathrm{efgh}$ & $5.9 \mathrm{def}$ & 26 \\
A5350 & $7.9 \mathrm{efgh}$ & $6.8 \mathrm{bcd}$ & 14 \\
Frisson & $7.9 \mathrm{efgh}$ & $7.2 \mathrm{bcd}$ & 9 \\
Goldrich & $7.6 \mathrm{fgh}$ & $6.8 \mathrm{def}$ & 9 \\
Elgat & $7.3 \mathrm{gh}$ & $5.8 \mathrm{def}$ & 21 \\
Congat & $7.1 \mathrm{fgh}$ & $5.5 \mathrm{def}$ & 22 \\
Hargrand & $3.1 \mathrm{i}$ & $2.6 \mathrm{f}$ & 15 \\
Pooled SD & 0.89 & 0.79 &
\end{tabular}

Each value is the mean of three replicates for cooked apricot; M1-M2 difference is calculated on the means.

For the same column, data with same letters do not differ significantly from each other whereas data with different superscripts differ significantly at the probability level $\mathrm{P}<0.05$; Pooled SD: Pooled standard deviation.

and $12 \mathrm{~J}$ respectively at M1 stage). Differences between M1 and M2 values expressed the impact of the maturity stage onto the evolution fruit texture, as key factor for the industrial process, the influence of the cultivar ranges between $9 \%$ for Vertige to more than $30 \%$ for Gaterie and Candide.

The dendrogram (Fig. 3) was issued from a hierarchical clustering based on both $\mathrm{W}_{\text {lim }}$ parameter from puncture test on fresh and cooked fruits and Kramer test, and on the 2 ripening stages (M1, M2). By this integrative analysis, cultivars were divided in 3 groups. Vertige appeared alone, keeping a high firmness whatever the process and the 2 tested ripening stages. Orangered, Candide, Bergarouge and Gaterie were in the same group, characterized by a high level of firmness and an impact of maturity stage. The third set joined all cultivars with a lower firmness, a high impact of maturity and of processing.

In our experiment, puncture tests were not correlated to global compression. These results highlight that puncture test on fruit slice (not on whole fruit), on a specific parenchyma area (only a tissular type) and in an orthogonal axis (transversal and not from epidermis to inner tissues) allowed to discriminate cultivars at similar global firmness levels.

Cooking led to marked loss of texture, with most varieties losing over $50 \%$ of their initial firmness in the puncture test, for both maturity stages. It also caused a reshuffling of the scale of texture of apricot varieties, as their hierarchy after thermal treatment was not fully in agreement with the one observed in fresh fruit, as observed by Ella Missang et al. (2011) on steamed apricots or Bourles, Mehinagic, Courthaudon, and Jourjon (2009) observed on vacuum-cooked apple. Thermal treatments soften the tissue by decreasing turgor pressure (Greve et al., 1994), and by solubilizing cell wall pectic substances, which separate the vegetable cells (Van Buren, 1979). Previous studies have shown that the mechanical strength of plant cells is provided by pressurization and biochemical changes of the pectic substances of cell wall (Nguyen et al., 2010). Basak and Ramaswamy (1998) suggested that the most probable reasons for textural loss variability is due to pectinmethyl-esterase (PME) activity and increased compactness of the cellular structure as a result of the elimination of air from the tissue.

\section{Conclusion}

The evolution of texture between fresh and cooked apricot was studied at a tissular level on a large range of cultivars. The work to limit $\left(\mathrm{W}_{\mathrm{lim}}\right)$ parameter appeared the most relevant variable, both with puncture or Kramer tests to compare cultivars. The cultivars tested presented different degrees of susceptibility to heat treatment, probably in relation with their physicochemical characteristics. The cultivars which appeared the best suited for processing, 


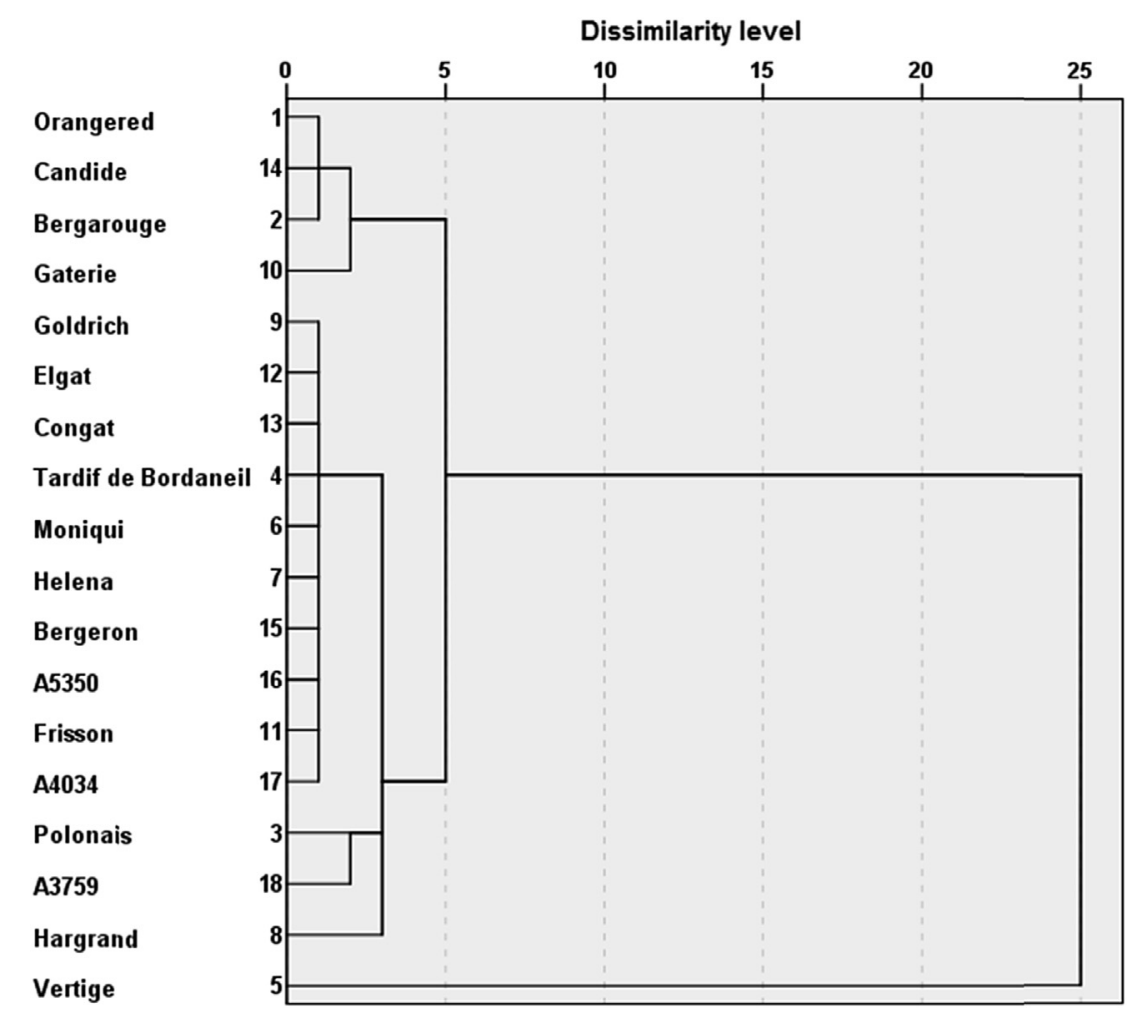

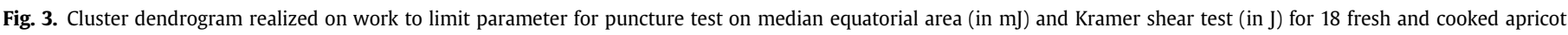
cultivars at two maturity stages.

with the less texture loss after cooking, were Vertige and, in a less extend, Candide, Gaterie, Orangered and Bergarouge in relation with their maturity stage. Studies on PME activities and tissular structure will be necessary to better understand the underlying biochemical or microstructural phenomena implicated in this texture loss, thus allowing identification of selection criteria for apricots meant for processing.

\section{Acknowledgements}

This work was supported by grants of Université d'Avignon (Prix Perdiguier) and of Moroccan ministry of higher education, scientific research and professional training to Jamal Ayour. We acknowledge financial support from the ANR (French National Research Agency) under the Sustainable Food System program ILLIAD (ANR-11-ALID006).

\section{Appendix A. Supplementary data}

Supplementary data related to this article can be found at http:// dx.doi.org/10.1016/j.lwt.2016.10.040.

\section{References}

Archibald, R. D., \& Melton, L. D. (1987). The anatomy of the fleshy pericarp of maturing Moorpark apricots, Prunus armeniaca. New Zealand Journal of Botany, $25,181-184$.

Basak, S., \& Ramaswamy, H. S. (1998). Effect of high pressure processing on the texture of selected fruits and vegetables. Journal of Texture Studies, 29, 587-601. Botondi, R., Crisà, A., Massantini, R., \& Mencarelli, F. (2000). Effects of low oxygen short term exposure on postharvest physiology and quality of apricots harvested at two ripening stages. Journal of Horticultural Science and Biotechnology, $75,202-208$.

Bourles, E., Mehinagic, E., Courthaudon, J. L., \& Jourjon, F. (2009). Impact of vacuum cooking process on the texture degradation of selected apple cultivars. Journal of Food Science, 74, 512-518.

Box, G. E. P., Hunter, W. G., \& Hunter, J. S. (1978). Statistics for experimenters, an introduction to design, data analysis and model building. New-York: Wiley and Sons, $352 \mathrm{pp}$.

Bruhn, C. M., Feldman, N., Garlitz, C., Harwood, J., Ivans, E., \& Marshall, M. (1991). Consumer perceptions of quality: Apricots, cantaloupes, peaches, pears, strawberries and tomatoes. Journal of Food Quality, 14, 187-195.

Chitarra, A. B., Labavitch, J. M., \& Kader, A. A. (1989). Canning-induced fruit softening and cell wall pectin solubilization in the 'Patterson' apricot. Journal of Food Sciences, 54, 990-992.

Costa, F. (2016). Mechanical investigation to assess the peel contribution in apple fruit. Postharvest Biology and Technology, 111, 41-47.

DeMartino, G., Massantini, R., Botondi, R., \& Mencarelli, F. (2002). Temperature affects impact injury on apricot fruit. Postharvest Biology and Technology, 25, 145-149.

Ella Missang, C., Maingonnat, J.-F., Renard, C. M. G. C., \& Audergon, J.-M. (2011). Texture variation in apricot fruit: Intra-fruit heterogeneity, impact of thinning and relation with the texture after cooking. Food Research International, 44, 46-53.

Ella Missang, C., Maingonnat, J.-F., Renard, C. M. G. C., \& Audergon, J.-M. (2012). Apricot cell wall composition: Relation with the intra-fruit texture heterogeneity and impact of cooking. Food Chemistry, 133, 45-54.

FAOSTAT Statistical Database, (2013). http://faostat.fao.org/site/291/Desktop Deafault.aspx?PageID=291. Accessed 23.07.15.

Greve, L. C., Shackel, K. A., Ahmadi, H., McArdle, R. N., Gohlke, J. R., \& Labavitch, J. M. (1994). Impact of heating on carrot firmness: Contribution of cellular turgor. Journal of Agricultural and Food Chemistry, 42, 2896-2899.

Grotte, M., Duprat, F., Loonis, D., \& Pietri, E. (2001). Mechanical properties of the skin and the flesh of apples. International Journal of Food Properties, 4, 149-161.

Kovacs, E., Meresz, P., Kristof, Z., \& Németh-Szerdahel, E. (2008). Ripening and microstructure of apricot. Acta Alimentaria, 37, 23-39.

Mallidis, C. G., \& Katsaboxakis, C. (2002). Effect of thermal processing on the texture of canned apricots. International Journal of Food Science \& Technology, 37, $569-572$.

Nguyen, L. T., Tay, A., Balasubramaniam, V. M., Legan, J. D., Turek, E. J., \& Gupta, R. (2010). Evaluating the impact of thermal and pressure treatment in preserving textural quality of selected foods. LWT - Food Science and Technology, 43, 525-534.

Van Buren, J. P. S. (1979). The chemistry of texture in fruits and vegetables. Journal of Texture Studies, 10, 1-23. 